\title{
Action Research in Hadith Literacy: A Reflection of Hadith Learning in the Digital Age
}

\author{
Tedi Supriyadi* \\ Universitas Pendidikan Indonesia \\ Bandung, Indonesia \\ https:/ / orcid.org/0000-0003-0307-1958 \\ J. Julia, Ani Nur Aeni and Elan Sumarna \\ Universitas Pendidikan Indonesia \\ Bandung, Indonesia \\ https:// orcid.org/0000-0002-0249-0264 \\ https:// orcid.org/0000-0002-3593-1732 \\ https://orcid.org/0000-0002-8960-2299
}

\begin{abstract}
When the internet has become the main reference source for academics and students in completing their assignments, critical attitudes towards information accessed via the internet, especially about hadith are often ignored. Critical attitude is needed to ensure the authenticity of a hadith because its discourse has a level of quality, be it sahih hadith (authentic, accepted) or da'if (rejected). Along with the development of internet technology, many false hadiths are circulating on the internet. Therefore, adequate literacy skills in reading and tracing the authenticity of a hadith are needed. This research provides examples of the results of collaborative team work to improve hadith literacy. Action Research Design was chosen to find solutions to problems through critical reflection in the process of learning Al-Qur'an. The Action Research procedures were combined with the Kern's 3R model namely Responding, Revising, and Reflecting. This study involved 398 students as research participants at one of the higher education institutions in West Java, Indonesia. This research resulted in several findings: 1) Six steps were taken to improve hadith literacy, namely the formulation of learning objectives, selection of media, update of the knowledge of hadith, understanding the learning media, application of learning media, and evaluation. 2) Two applications were used as learning media in improving hadith literacy, namely the science of hadith and the Ensiklopedi Hadits Kitab 9 Imam (EHK9I, Encyclopedia of Hadith in the book of 9 Imams). 3) The reflective actions and the integration of the two applications showed an increase in three aspects of literacy namely data literacy $(54.33 \%)$, technological literacy $(63.07 \%)$, and human literacy related to narration of the hadith (93.59\%). It can be
\end{abstract}

*Corresponding Author: Tedi Supriyadi, Email: tedisupriyadi@upi.edu 
concluded that the steps taken by utilizing the two applications as learning media can improve the participants' ability to trace and determine the authenticity of a hadith.

Keywords: literacy; hadith; digital native; action research; takhrij hadith

\section{Introduction}

One guiding principle the millennials must have in studying Islam or any scientific work on Islam is to use information from original and reliable sources (Alkhatib, Monem \& Shaalan, 2017; Karim \& Hazmi, 2005; Luthfi, Suryana \& Basari, 2018). In the study of hadith, it is compulsory to refer to the original primary reference sources namely the books of hadith by the ulama. Works that are often used as references and recommended in hadith discussions are known as kutub sittah or the six hadith books and some even call them as kutubu tis'ah or the nine books of hadith (Mohamad \& Mohamad, 2017; Suliaman \& Yaakob, 2019; Suliaman et al., 2018).

Along with the presence of internet technology as a communication tool and information provider, this principle is in fact often ignored. The internet has become the main reference source for academics and students in completing their assignments (Karim \& Hazmi, 2005). In addition, the development of internet technology has made the millennials rely more on social media as a tool to get information such as Instagram, Facebook, Twitter, WhatsApp groups, and so on (Wahyuningsih, 2019).

Ironically, obtaining the information on hadith from the internet or social media is not accompanied by a critical attitude to differentiate which hadith is authentic. Students need to have the ability to investigate shahih hadith through the following criteria: a. Sanadnya continued (iitishal al-sanad); $b$. The narrator is fair ("adalat al-rawi); c. The narrator is dhabit (dhabth al-rawi); d. Avoiding the syadz ("adam al-syadz); e. Avoid illat ("adam" illat). As an example, the millennial generation rarely crosschecks the hadith quotations spread in the cyberspace with the books of hadith. Checking on the books of hadith is important to test whether or not a person's arguments are strong when discussing Islamic topics. Quoting Al-Qur'an or hadith is a rhetorical strategy to build arguments on all topics (Boutz, Benninger \& Lancaster, 2019).

Conducting a hadith cross-check as a manifestation of a critical attitude towards hadith information is oriented on to two things. First is whether the hadith quoted or used in the argument is in the books of the hadith or not. Second, the quality of the hadith used as an argument in the topic. The hadith discourse is always confronted with the degree of quality of a hadith. Analysis is required to conclude whether a hadith, as the footing, is accepted or rejected (Najeeb, 2014; Najiyah, Susanti, Riana \& Wahyudi, 2017). The activity of searching the hadith and revealing the quality of a hadith is called takhrij hadith (Hidayat, 2018; Qomarullah, 2016).

The critical attitude embodied through the takhrij hadith is a necessity for the millennials who have an interest in Islamic topics. This is important because the 
spread of false hadith continues to increase via the internet or social media and has become a new threat that must be seriously eradicated by Muslims living in this digital world (Usman A.H, 2018). Therefore, insight, skills and high motivation are needed to carry it out as an effort to prevent false hadith from circulating online as to filter information related to the hadith. Therefore, ones' understanding and practice of Islam should have strong legislation foundation. The reason for this is that the hadith is a fundamental source of Islamic teachings after Al-Qur'an (Baraka \& Dalloul, 2014; Najeeb, 2014).

Based on the problems, this study aims at analyzing the steps of action in improving the takhrij hadith ability of the millennial generation based on information technology. The limitations of this study are formulated in the questions: "How are the steps to increase takhrij hadith ability for the millennial generation?" and "What information technology can improve the takhrij hadith ability for the millennial generation?". In specific, this study hypothesized that the utilization of Encyclopedia of Hadith in the book of 9 Imams (hereinafter abbreviated as EHK91) that the students' critical thinking ability on hadith circulated on the internet can be developed.

\section{Theoretical Framework}

The hadith is the words and deeds of the prophet Muhammad (Baraka \& Dalloul, 2014; Najeeb, 2014). Not only that, it is also defined as his provisions, agreements and ideals(Al-Fadli, 2011; Ali, 2013; Brown, 2017; Kamali, 2014). In the perspective of Islam, the hadith is an important tool in understanding Al-Qur'an as the first and foremost source of Islamic teachings (Baraka \& Dalloul, 2014), hence the hadith is the second source of Islamic teachings after Al-Qur'an (Najeeb, 2014; Najiyah et al., 2017).

There are two parts in a hadith. The first part is the original content (narration) or matan, (المنن.) The second part is the string of narrators who conveyed the narration, or isnad (إسناد ). Isnad is the list narrators who were listed chronologically (the person who a narrator heard the hadith from), traced back until the first Hadith narrator of the matan and the matan itself (Azmi \& Badia, 2010). For about 15 centuries, Muslims were relying on isnad to differentiate hadiths that are accepted (Sahih) and rejected (Da'if). The scholars of Hadith assess them using the isnad and the narrators making the string (Najeeb, 2014). Therefore, in the science of hadith, a research on isnad is Hadith essential. To find out the authenticity of a hadith, Hadithhadith scholars adhere to defined steps of isnad. The steps are believed to be traditional (Baraka \& Dalloul, 2014).

A frequently used reference in the investigation of hadith is the "six books called kutubu sittaah", namely Sahih Al-Bukhari, Sahih Muslim, Sunan Abu Daud, Sunan Al Tirmidzi, Sunan Ibnu Majah and Sunan Al Nasa'i (Najeeb, 2014). Most of the hadith experts believe that if a hadith alleged to be based on the Prophet is found in the canonical hadith collection, especially in Sahih Bukhari and Muslim, then the hadith is definitely sourced from the Prophet (Masrur, 2007). However, in contrast to most hadith experts, G.H.A. Juynboll (1935-2010 AD) with his common link theory, as revealed by Arifah (2019) and Masrur (2007), although a 
hadith has been recorded in al-kutub al-sittah, the hadith does not necessarily come from the Prophet. This indicates that to know the authenticity of the hadith two stages are required. The first is to trace the hadith in the canonical books and the second is to analyze the series of isnad to determine the quality by the methods established by the ulama. In the science of hadith, this is known as the takhrij hadith (Hidayat, 2018; Qomarullah, 2016; Suliaman et al., 2018).

The above steps are linked to one's literacy skills. Literacy is not limited to reading and writing activities but is also related to the demand to understand information critically and analytically (UNESCO, 2003). The advances in information technology and the internet which result in abundant digital information resources demand people to have digital literacy capabilities, namely special abilities in using digital information (Miftah, Rizal \& Anwar, 2016).

So far, there have been many efforts in studying the hadith, for example the multimedia-based Aplikasi Seratus Satu Hadis tentang Budi Luhur (A Hundred and One Hadith on Highest Virtue Application) which was developed by Diki Silviadi. However, the purpose of the application was to assist students in memorizing hadith (Tresnawati, Satria \& Silviadi, 2016). In addition, its features and contents are not representative enough to explore the quality of the hadith.

Rakhmah (2016) wrote an article on the making of E-Hadits, a Java Eclipse based smartphone application. She mentioned that the weaknesses of the application were that contents and features were still limited and did not lead to providing information about isnad as an important aspect in tracing the authenticity of the hadith (Najeeb, 2014).

The Perpustakaan Shamela application is one of the most helpful systems in learning hadith (Ghozali, 2017; Najeeb, 2014). This application helps investigating the "narrator chain" and provides accurate information about matan and isnad, as well as provides information on all important details about the narrators. However, this application is not automatically able to judge the quality and all parts of the digital library use Arabic.

Another application that is quite representative in studying the hadith in terms of information on both matan and isnad, which are important elements in the hadith (Azmi \& bin Badia, 2010; Baraka \& Dalloul, 2014; Najeeb, 2014), is the Ensiklopedi Hadits Kitab 9 Imam (hereinafter abbreviated as EHK9I, Encyclopedia of Hadith in the book of 9 Imams) developed by Lidwa Pustaka. This application is equipped with punctuation marks and translations, and it is a digitalized version of the 9 books of hadith and other features that support the ease of learning the hadith.

These works show a fairly high interest in studying the science of hadith and strive to utilize new techniques to present them in an application as a learning medium. This research is focused on the pedagogic aspect as an effort to improve students' ability to trace the authenticity of a hadith using available information technology as a learning medium. 


\section{Method}

\subsection{Design}

This research employs Action Research (AR) design because AR seeks to explore problems to find solutions (Creswell, 2002). This is in line with the problem of students' critical attitudes in receiving, reviewing, and understanding hadith information as a source of Islamic teachings. In addition, AR provides vast space for researchers to find new innovations to make changes suitable to conditions and needs (Darwis, 2016). The exclusive characteristic of AR is that the users can make improvements and solve problems (Bozkus \& Bayrak, 2019; Greenwood \& Levin, 2006).

In line with the above, AR is popular among researchers to solve problems in the pedagogic field. Several examples of research using AR are J. Julia research titled Technology Literacy and Student Practice: Lecturing Critical Evaluation Skills (Julia \& Isrokatun, 2019), Niemi (2018) titled Five Approaches to Pedagogical Action Research and Edwards-Groves and Kemmis (2016) titled Pedagogy, Education, and Praxis: Understanding New Forms of Intersubjectivity through Action Research and Practice Theory. This current article's authors have implemented AR in their research (Suherman, Supriyadi, \& Cukarso, 2019; Supriyadi \& Julia, 2019; Supriyadi, Julia, \& Iswara, 2019; Supriyadi, Julia, Iswara \& Aeni, 2019). In addition, this research design can be used as an effort to understand self-practice to enable improvements in every action taken (Kemmis \& McTaggart, 2005; Kemmis, McTaggart \& Nixon, 2013; McTaggart, 1994). Using AR, the researcher can apply the planning, implementation, and reflection on every research step (McTaggart, 1996).

In specific, the distinctive feature of $A R$ is the principle of collaboration in conducting research (Bruce, Flynn \& Stagg-Peterson, 2011; Creswell, 2002; Ferguson-Patrick, 2007; Jaipal \& Figg, 2011; Leeman, van Koeven \& Schaafsma, 2018; Somekh, 2010). In the collaborative action research in the field of education, there is cooperation between the teachers, or between the teachers and the researchers (Messiou, 2019; Zech, Gause-Vega, Bray, Secules \& Goldman, 2000). This research, therefore, involved several parties. .

\subsection{Research Participant and Site}

The participants of this research were students at one of the public higher education institutions taking Islamic religious education course. There were 398 students consisting of 127 males and 271 females in one batch in three study programs. The participants were from several regions in Indonesia namely West Java, Central Java, Jakarta, and West Nusa Tenggara. The sampling technique was purposive sampling in which the researcher determined the sample with certain considerations and criteria in accordance with the objectives of the study. The consideration was that every Muslim is required to understand and practice the hadith. The sample criteria are students who were taking Islamic education courses. In addition, the participants were in the digital native criteria. According to Prensky, (2001) one of the initiators of the digital natives generation theory, digital natives have the characteristics of being born in the 1980s and thereafter, being born in the digital technology environment. 
Considering the collaborative features of $\mathrm{AR}$, this research involved several other parties. They were lecturers and the religious-based students' activity unit. The researchers as lecturers of Islamic religious education course collaborated with peers who also teach the course. One lecturer had a special expertise in the field of hadith. In addition, the researchers also collaborated with one of the student activity units in the religious field to be involved in a series of actions taken.

\subsection{Research Procedure}

The procedure in this research combined the steps in AR design with the theory developed by Kern (Kern, 2000) in improving literacy known as the 3R, namely Responding, Revising, and Reflecting. Responding involves two parties, namely lecturers and learners, and they have a reciprocal relationship. Simply put, this first $\mathrm{R}$, Responding, is an attempt to portray the problem of student literacy skills in hadith learning and to map students' initial abilities in hadith literacy. This stage is the pre-action analysis. The second R, Revision, includes various activities in designing improvement efforts based on problems found in the, the media used, and the improvements made in learning. The third R, Reflecting, is similar to evaluation, which is the process of evaluating what has been done, what was seen, and what was felt during the learning or it is called the postaction analysis.

The above 3R procedure showed a reciprocal relationship between the lecturers and the students. In the first $\mathrm{R}$, Responding, the students responded to the given task of reading, tracing, and analyzing the hadith; while the lecturers responded by providing feedback to help the students reach a certain level of accuracy. In the second R. Revision, Hadith Insight Test was done to measure their knowledge about hadith by the lecturers and performed by the students. In the third R, Reflecting, the lecturers evaluated the results of the first two Rs; while the students were asked about what was seen, and what was felt during the learning.

\subsection{Data Collection}

The data were collected by means of surveys, observations, and semi-structured interviews. The survey used the scale from Likert and Guttman (Allen \& Seaman, 2007; Widhiarso, 2011) and was distributed using Google Documents. In today digital era, Google Documents has become a profitable and easy-to-use survey tool (Allen \& Seaman, 2007; Brigham, 2014; Chiu, Cheng \& Wu, 2016; Lin, Chang, Hou \& Wu, 2016; Travis, 2010; Widhiarso, 2011). Therefore, the research instrument used consisted of observation guidelines, interview guidelines, and questionnaires (Appendix 1).

\subsection{Development of Literacy Indicators}

To measure the participants' level of literacy in the field of hadith, a rubric was formulated. This rubric is a development of the three aspects of literacy ability as stated by Furqon (2018). The developed indicators were related to the aspects of human literacy and the narrators of the hadith, and we expect that the students could at least master $75 \%$ of the indicators listed in Table 1 . This was necessary because tracing the authenticity of a hadith is inseparable from its history and 
credibility of the narrators of the hadith (Karim \& Hazmi, 2005; Najeeb, 2014). The development is described in the following Table 1.

Table 1. Hadith Literacy Rubric

\begin{tabular}{|c|c|c|c|c|}
\hline No & $\begin{array}{c}\text { Literacy } \\
\text { Aspect }\end{array}$ & Description & Indicator & Target \\
\hline 1 & $\begin{array}{l}\text { Hadith Data } \\
\text { Literacy }\end{array}$ & $\begin{array}{l}\text { The ability to read, } \\
\text { analyze and make } \\
\text { conclusions of } \\
\text { thinking based on } \\
\text { obtained data and } \\
\text { information (big } \\
\text { data) }\end{array}$ & $\begin{array}{l}\text { 1. Able to find and collect } \\
\text { thematic hadiths. } \\
\text { 2. Able to distinguish elements } \\
\text { of the hadith (matan and isnad). } \\
\text { 3. Able to mention the } \\
\text { source/primary book related } \\
\text { to a hadith. } \\
\text { 4. Able to express the content of } \\
\text { a hadith according to the } \\
\text { explanation of ulama. }\end{array}$ & $75 \%$ \\
\hline 2 & $\begin{array}{l}\text { Hadith } \\
\text { Technology } \\
\text { Literacy }\end{array}$ & $\begin{array}{l}\text { Ability to } \\
\text { understand } \\
\text { machines and } \\
\text { technology } \\
\text { applications, and do } \\
\text { work using } \\
\text { technology-based } \\
\text { products }\end{array}$ & $\begin{array}{l}\text { 1. Able to utilize information } \\
\text { technology in studying hadith. } \\
\text { 2. Able to search for and choose } \\
\text { information technology } \\
\text { related to the hadith } \\
\text { appropriately } \\
\text { 3. Able to understand the } \\
\text { features in the hadith } \\
\text { information technology being } \\
\text { used }\end{array}$ & $75 \%$ \\
\hline 3 & $\begin{array}{l}\text { Human } \\
\text { Literacy } \\
\text { related to } \\
\text { the } \\
\text { Narrator of } \\
\text { Hadith }\end{array}$ & $\begin{array}{l}\text { Communication } \\
\text { skills, collaboration, } \\
\text { critical thinking, } \\
\text { creativity and } \\
\text { innovation related } \\
\text { to the hadith } \\
\text { narrators }\end{array}$ & $\begin{array}{l}\text { 1. Able to express the quality of } \\
\text { a hadith accompanied by the } \\
\text { narrator's narration analysis. } \\
\text { 2. Able to respond to a hadith } \\
\text { that is used as a basis for } \\
\text { someone }\end{array}$ & $75 \%$ \\
\hline
\end{tabular}

\section{Results and Discussion}

\subsection{Pre-Action Analysis}

At this stage, issues related to the participants' ability in the field of literacy were explored. This step was done to obtain an overview of the participants' initial ability in the field of hadith based on the developed indicators. The indicators were (1) data literacy, which is the ability to trace a number of hadiths on certain topics, (2) technology literacy, which is the media and methods used in tracing the hadith, and (3) human literacy, which is the ability to analyze the quality of the hadith through the study of narrators of hadith.

To measure the 398 research participants, a number of tests in the form of questions with the topic of shalat (prayer) were given. This topic was chosen because shalat is the most fundamental ritual obligation for a Muslim. In general, shalat is defined as reciting (the prayers), supplicating, and strengthening the 
relationship with God (Parvez, 2016). Therefore, the practice of shalat for a Muslim must surely follow the examples and teachings of prophet Muhammad SAW in both his readings and movements, as in the words of the Prophet Muhammad SAW "Pray you as you see me pray" (Al Asqalani, 2007). The participants were tested whether they could search information about the hadith in accordance with the specified topic, to find out the media that they used for searching the information and how they find assess the hadith's authenticity. The test results can be seen in the following Table 2:

Table 2. Results of Hadith Literacy Pretest

\begin{tabular}{|c|c|c|c|c|}
\hline No & $\begin{array}{l}\text { Literacy } \\
\text { Aspect }\end{array}$ & Description & Indicator & $\begin{array}{c}\text { Percentage } \\
(\%)\end{array}$ \\
\hline 1 & $\begin{array}{l}\text { Hadith Data } \\
\text { Literacy }\end{array}$ & $\begin{array}{l}\text { The ability to } \\
\text { read, analyze } \\
\text { and make } \\
\text { conclusions of } \\
\text { thinking based } \\
\text { on obtained } \\
\text { data and } \\
\text { information } \\
\text { (big data) }\end{array}$ & $\begin{array}{l}\text { a) Able to find and collect } \\
\text { thematic hadiths. } \\
\text { b) Able to distinguish elements } \\
\text { of the hadith (matan and isnad). } \\
\text { c) Able to mention the } \\
\text { source/primary book related } \\
\text { to a hadith. } \\
\text { d) Able to express the content of } \\
\text { a hadith according to the } \\
\text { explanation of ulama. }\end{array}$ & $\begin{array}{l}24.6 \% \\
24.6 \%\end{array}$ \\
\hline 2 & $\begin{array}{l}\text { Hadith } \\
\text { Technology } \\
\text { Literacy }\end{array}$ & $\begin{array}{l}\text { Ability to } \\
\text { understand } \\
\text { machines and } \\
\text { technology } \\
\text { applications, } \\
\text { and do work } \\
\text { using } \\
\text { technology- } \\
\text { based products }\end{array}$ & $\begin{array}{l}\text { a) Able to utilize information } \\
\text { technology in studying hadith. } \\
\text { b) Able to search for and choose } \\
\text { information technology } \\
\text { related to the hadith } \\
\text { appropriately } \\
\text { c) Able to understand the } \\
\text { features in the hadith } \\
\text { information technology being } \\
\text { used }\end{array}$ & $100 \%$ \\
\hline 3 & $\begin{array}{l}\text { Human } \\
\text { Literacy } \\
\text { related to } \\
\text { the } \\
\text { Narrator of } \\
\text { Hadith }\end{array}$ & $\begin{array}{l}\text { Communication } \\
\text { skills, } \\
\text { collaboration, } \\
\text { critical } \\
\text { thinking, } \\
\text { creativity and } \\
\text { innovation } \\
\text { related to the } \\
\text { hadith narrators }\end{array}$ & $\begin{array}{l}\text { a) Able to express the quality of } \\
\text { a hadith accompanied by the } \\
\text { narrator's narration analysis. } \\
\text { b) Able to respond to a hadith } \\
\text { that is used as a basis for } \\
\text { someone }\end{array}$ & $1.8 \%$ \\
\hline
\end{tabular}

$n=398$ participants

Table 2 presents that in the aspect of data literacy; only 1 indicator was able to be represented by all participants as $398(100 \%)$ participants were able to collect the hadiths thematically. For the second and the third indicators, only 98 (24.6\%), and the fourth indicator only $70(17.59 \%)$ participants were able to represent their abilities. This means that from several indicators, only one indicator from the aspect of data literacy was able to be represented by more than $80 \%$ of the 
participants and other indicators were below $80 \%$. Thus, the participants' ability on the other indicators in data literacy was still weak.

In the aspect of technology literacy as shown in Table 2, 398 (100\%) participants represented the ability to use information technology in tracing and collecting hadiths related to the topic of shalat. Furthermore, based on this information, all of them were surveyed to explore what kind of information technology they used in searching and gathering hadiths related to the topic of prayer. The survey results are as follows. There were $322(80.90 \%)$ participants who used blogs, 25 $(6.28 \%)$ used Twitter, 39 (9.80\%) used Facebook, and $12(3.2 \%)$ used hadith applications. It can be seen that in the aspect of technological literacy, only 12 (3.2\%) participants showed the ability to search for and choose information technology that is relevant to the hadith.

Furthermore, to find out what applications they used in tracing the hadith, semistructured interviews were carried out with the 12 participants who claimed to use the hadith applications. The question was, "What application did you use to trace the hadith?"

From the results of the semi-structured interviews, three participants $(24 \%)$ used the Maktabah Syamilah software, four (33.3\%) used the Jawami'ul Kalim software, and five $(41.67 \%)$ used the EHK9I software. Based on the answers, a follow-up question was asked, "Do you understand the function of each feature available in the application?" Nine participants (75\%)responded that they understood it and three (24\%) participants did not understand it, especially the softwares in Arabic, namely Jawami'ul Kalim and Maktabah Syamilah. Therefore, in the aspect of technological literacy, only 9 participants $(2.26 \%)$ understood the features of the application they used.

In the aspect of human literacy as shown in Table 2, nine (2.26\%) participants showed the ability of indicator 1 namely expressing the quality of a hadith. The reason for this was assumed that the information technology they used presented information related to the quality of a hadith. Meanwhile, 389 (97.74\%) did not show this ability because the information sources they used were less relevant. As for the second indicator in the aspect of human literacy, seven $(1.76 \%)$ participants were able to represent the ability to respond to the hadith raised by his friend when presenting the results of his assignment.

Based on that test results, the ability to distinguish the elements of the hadith as in the second indicator in the aspect of literacy and the ability to determine the quality of the hadith as in the first indicator in the aspect of human literacy, it was suspected that the participants' insight about the science of hadith has not been evenly distributed. Therefore, the extent of experience and insight that the participants gained about hadith were explored by using a survey.

The results showed that $398(100 \%)$ participants claimed to have studied the science of hadith. A total of 300 (75.4) participants stated that they learned lessons about hadith in school and 278 (69.8\%) participants received hadith lessons outside of school. Regarding question number 3, the participants experience in studying hadith was explored by conducting semi-structured interviews with 3 
participants. The question asked was "Where did you get hadith lessons other than school?" Participant 1 answered "from pesantren (Islamic boarding school)." Participant 2 from Islamic study groups in their neighborhood and four participants answered "from parents at home."

In addition to exploring about the participants' experience in studying the hadith, there was also a survey to explore the extent of insight they had gained from the experience of studying the hadith in the participants' perspectives. The survey results above show a gap with the results of the test as shown in Table 2, especially in question no. 2, a number of $365(91.70 \%)$ people stated that they understood the elements in a hadith while the test results showed the ability to distinguish elements of hadith namely matan and sanad only amounted 98 $(24.62 \%)$ people. Furthermore, in question no. 3, a number of 351 (88.19\%) stated that they understood the distribution of hadith in terms of quality, but the test results that showed the ability to express the quality of a hadith were only 9 $(2.26 \%)$ people. However, this survey results are a recognition form of the ability of the particpant's own perspective, but the test evidence shows different results. Therefore, the test results in Table 2 become a reference for us as a portrait of the participant's initial ability in hadith literacy.

Based on the information from question 1 on the understanding of the basics in hadith learning which are the terminology and division, it was suspected that there was a disparity of understanding among the participants because in the hadith discourse there are also terms such as hadith, sunnah, khabar and atsar (Nasr, 2013; Nirwana, 2012; Suryadi, 2011). Therefore, a number of tests were administered in the form of questions to measure whether the subjets had an understanding of the terminology of hadith and its divisions. The test results showed that $124(31.15 \%)$ participants had an understanding which is different from the participants' claim as in Table 2 that 323 (81.15\%) participants understood the terminology and types of hadith. It can be concluded that the participants' insight related to the science of hadith needs to be improved.

\subsection{Pre-Action Evaluation}

The results of the pre-action analysis implied that the participants' literacy in hadith was still very minimal and needed to be improved. This can be seen from the data on the average percentage obtained in each aspect of literacy. The percentages were added up and divided by the number of indicators in each aspect.

The data literacy was $41.71 \%$, technological literacy was $35.09 \%$, and human literacy was $2.01 \%$, which were assessed using indicators presented in Table 1. This means that the participants' hadith literacy was very minimal, especially in the problem of human literacy, which was to determine the authenticity of a hadith through the study of the narrators of the hadith.

In addition to the above aspects, the literacy on appropriate and representative technology in finding hadith information also needed to be strengthened because the participants tended to rely more on social media and blogs that are not representative in providing hadith information. This indicated that they have not 
been able to choose the right information technology in accessing hadith information. Likewise, the data literacy also needed to be strengthened because data literacy is not only the ability to collect hadiths but also relates to their insights about the science of hadith.

In the pre-action stage the average number of participants who were able to represent hadith literacy in each aspect was below $50 \%$. Through the focus group discussions, target number of participants capable of representing the literacy ability of hadiths would be raised at a minimum of $75 \%$.

\subsection{Action Implementation}

To achieve the target, the steps to improve the hadith literacy were structured. The steps referred to Kern's (2000) theory, namely Responding, Revising and Reflecting (3R). The first R, Responding, was implemented in the pre-action stage by capturing the participants' initial abilities in hadith literacy. Therefore, in the action stage, the second $\mathrm{R}$ (Revision) was implemented, which includes various activities in designing improvement efforts based on the problems, starting from the planning, the media used, and the implementation of improvements in learning.

\subsubsection{Step 1. Formulation of Hadith Learning Objectives}

At this stage, the lesson plans to improve the literacy of the participants in tracing the authenticity of the hadith were made. Tracing the authenticity of a hadith is closely related to the ability to perform the takhrij hadith. Hence, the learning objectives made referred to the objectives of the takhrij hadith namely:

a. Identifying the place of hadith by referring to its fundamental source

b. Identifying narrators of hadith by assessing their position from the view of al-Jarh wa al-Ta'dil, a systematic approach to criticize the position of the narrator

c. Stating sanad (chain of narrators of hadith) related to their connection and matan (narrative content).

d. Determining the authenticity of a hadith, namely sahih (acceptable), hasan (good), da if (weak) or maudu' (fabricated or false).

e. Recognizing the status and reliability of the hadith and its category based on sanad and also matan (Al-Rajan, 2018; Qomarullah, 2016; Zulkipli et al., 2017).

\subsubsection{Step 2. Selection of Hadith Learning Media}

To achieve the learning objectives associated with the characteristics of the participants as digital natives attached to the world of internet technology, it is necessary to use media that can facilitate the characteristics of the participants and the purpose of learning. Therefore, the learning media is a necessity in the learning process (Gillen, Staarman, Littleton, Mercer \& Twiner 2, 2007; Peppler \& Kafai, 2007; Salomon \& Clark, 1977; Willett, 2007). Based on the results of focus group discussions, at least 10 characteristics were needed to achieve the takhrij hadith learning objectives. The characteristics are as follows:

1. Presenting the hadith source

2. Presenting the position of the hadith in the book and chapter

3. Presenting the sanad chain information 
4. Presenting the matan (hadith content)

5. Presenting the sanad hadith reinforcement for another sanad hadith and the similarity of matan (Syawahid and Mutaba'at)

6. Presenting the narrator's biography

7. Presenting the type of hadith based on sanad

8. Presenting the type of hadith based on matan

9. Presenting the law of the hadith

10. Presenting the Indonesian translation

Based on the 10 criteria, existing hadith learning media were analyzed. The media were those applications that had been used by the 12 participants in the pre-action stage and relevant learning media that had not been used by the participants. At least five applications were reviewed with reference to the 10 criteria. The results of the review are presented in the following Table 3:

Table 3. Results of Hadith Learning Media Analysis

\begin{tabular}{|c|c|c|c|c|c|c|}
\hline \multirow[b]{2}{*}{ No } & \multirow[b]{2}{*}{ Criteria } & \multicolumn{5}{|c|}{ Application } \\
\hline & & $\begin{array}{c}\text { Ensiklopedi } \\
\text { Hadits } \\
\text { Kitab } 9 \\
\text { Imam }\end{array}$ & $\begin{array}{l}\text { Maktabah } \\
\text { Syamilah } \\
\text { Version } 3\end{array}$ & $\begin{array}{l}\text { Jawa } \\
\text { mi'ul } \\
\text { Kalim }\end{array}$ & $\begin{array}{l}\text { Mawsu'A } \\
\text { h al- } \\
\text { Hadith al- } \\
\text { Nabawi } \\
\text { al-Syarif }\end{array}$ & $\begin{array}{c}\text { Al- } \\
\text { Kutub } \\
\text { al-Tis'ah }\end{array}$ \\
\hline 1 & $\begin{array}{l}\text { Presenting the hadith } \\
\text { source }\end{array}$ & $\checkmark$ & $\checkmark$ & $\checkmark$ & $\checkmark$ & $\checkmark$ \\
\hline 2 & $\begin{array}{l}\text { Presenting the position } \\
\text { of the hadith in the } \\
\text { book and chapter }\end{array}$ & $\checkmark$ & $\checkmark$ & $\checkmark$ & $\checkmark$ & $\checkmark$ \\
\hline 3 & $\begin{array}{l}\text { Presenting the sanad } \\
\text { chain information }\end{array}$ & $\checkmark$ & $\checkmark$ & $\checkmark$ & $\checkmark$ & $\checkmark$ \\
\hline 4 & $\begin{array}{l}\text { Presenting the matan } \\
\text { (hadith content) }\end{array}$ & $\checkmark$ & $\checkmark$ & $\checkmark$ & $\checkmark$ & $\checkmark$ \\
\hline 5 & $\begin{array}{l}\text { Presenting the sanad } \\
\text { hadith reinforcement } \\
\text { for another sanad hadith } \\
\text { (syawahid and } \\
\text { mutaba'at) }\end{array}$ & $\checkmark$ & $\checkmark$ & $\checkmark$ & $x$ & $\checkmark$ \\
\hline 6 & $\begin{array}{l}\text { Presenting the narrator } \\
\text { biography }\end{array}$ & $\checkmark$ & $\checkmark$ & $\checkmark$ & $x$ & $\checkmark$ \\
\hline 7 & $\begin{array}{l}\text { Presenting the type of } \\
\text { hadith based on sanad }\end{array}$ & $\checkmark$ & $\checkmark$ & $\checkmark$ & $X$ & $\checkmark$ \\
\hline 8 & $\begin{array}{l}\text { Presenting the type of } \\
\text { hadith based on matan }\end{array}$ & $\checkmark$ & $\checkmark$ & $\checkmark$ & $x$ & $X$ \\
\hline 9 & $\begin{array}{l}\text { Presenting the law of } \\
\text { hadith }\end{array}$ & $\checkmark$ & $X$ & $\checkmark$ & $\checkmark$ & $\checkmark$ \\
\hline 10 & $\begin{array}{l}\text { Presenting the } \\
\text { Indonesian translation }\end{array}$ & $\checkmark$ & $X$ & $x$ & $X$ & $x$ \\
\hline
\end{tabular}

Based on the table, out of the 5 available applications, only the EHK9I meets the established criteria. Therefore, the media used in the effort to improve the participants' ability to trace the authenticity of a hadith was the EHK9I application. Additionally, for practical purposes, the application used was the mobile phone version because almost all of the participants had a smart phone. 
The EHK9I application is an application designed by Lidwa Centralka. It contains several features including:

1. Available on Android, iOS and Windows

2. Contains 62,000 hadith from 9 prominent imams.

3. Presents highlights, notes, share, and copy hadith

4. Presents the related hadith complete with degrees

5. Presents the narrators' information complete with statistics

6. Presents thematic collections of hadith and types of hadith

7. Contains a search engine feature to search by hadith number or hadith text.

In addition to the features, there were several information presented in every hadith display as in Figure 1.

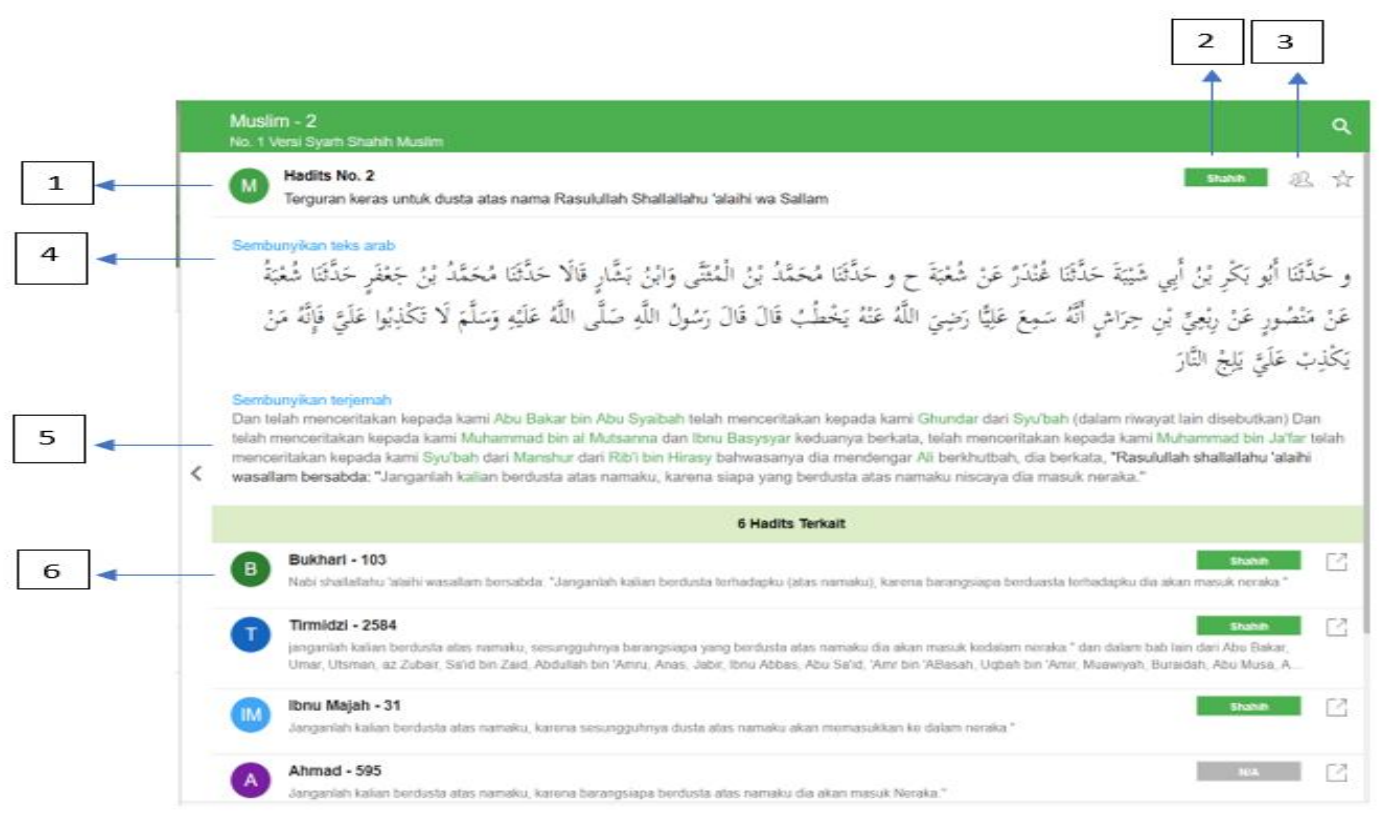

Figure 1. The display of Hadith EHK9I Application

The display of the hadith in this application provided the following information:

1. The number of hadith sequence from a book

2. The quality or degree of a hadith (hadith law)

3. Isnad information

4. Hadith text to ease reading

5. The translation of Arabic texts that help to understand the hadith text

6. Several hadiths that are relevant to the hadiths in display

In addition to using the EHK9I application, the Android-based e-book application, Ulumul Hadith, was utilized to strengthen the participants' knowledge related to the science of hadith.

This application was designed by Az-Zikr Studio. It presents information related to concepts in the study of hadith science in terms of the meaning of the hadith, division of the hadith, types of hadith, elements of a hadith, and so on. 
Thus, there were two applications to be used in an effort to improve literacy skills in tracing the hadith. However, this research is focused on the EHK9I application, and the second application was an enrichment to support the participants' understanding and skills in carrying out the takhrij hadith.

\subsubsection{Step 3. Update of Hadith Insight using Ulumul Hadits Application}

In this step, a number of materials related to the science of hadith were given to the participants classically. The participants were instructed to search and download the application and then install it.

In advance, the features available in the application were explained. The Ulumul Hadits application provided a number of materials that include the terminology of the hadith, the scope of the hadith study, elements of the hadith, and the types and quality of the hadith. The provision of material was done in three meetings. In each meeting the participants received a task to review the content of the material in the application to be discussed in the next meeting.

After providing the materials, all participants were tested by asking them several questions to measure their knowledge about hadith through Hadith Insight Test. The result is presented in Table 4.

Table 4. Hadith Insight Test Results

\begin{tabular}{lcc}
\hline Scoring Aspect & Number & Percentage \\
\hline Understand the meaning and types of hadith & 398 & 100 \\
$\begin{array}{l}\text { Differentiate matan dan sanad } \\
\begin{array}{l}\text { Understand the classification of hadith by its quality and } \\
\text { requirements }\end{array}\end{array}$ & 381 & 95.72 \\
\hline
\end{tabular}

Table 4 shows that the participants' level of mastery of the science of hadith. Based on the three assessment indicators, there were a number of improvements. In terms of the hadith terminology, 398 (100\%) participants showed understanding in the post-test which means there was an increase of $68.85 \%$ from 124 (31.15\%) participants. In the second assessment aspect, 381 (95.72\%) participants showed the ability to distinguish the matan and sanad of hadith. Compared to the test results in Table 2, which was 98 (24.62\%) participants, there was an increase of $283(71.1 \%)$ participants. Furthermore, in the aspect of understanding the classification of the hadith and the requirements, $383(96.23 \%)$ participants showed the ability. The test results in Table 2 only showed $9(2.26 \%)$ thus it increased by 374 (93.96\%) participants.

The test results above are the barometer of the theoretical mastery of hadith science. Therefore, to ensure that the participants' theoretical mastery was applicable, it was necessary to prove their ability by practicing the takhrij hadith. The practice required a representative media which was the EHK9I application. Therefore, the participants needed to have and understand how the application works. 


\subsubsection{Step 4. Understanding the EHK9I Application}

The participants were instructed to download the EHK9I application from https://store.lidwa.com. Android, iOS, and Windows versions were available and the participants chose a version suitable with the facilities they had. From their observations, they chose to download the Windows version because all participants were Windows-based users.

After they downloaded the application, they were guided throughout the installation process. Shortly after the installation, there was an offer to upgrade to the pro version. After they received explanation about the different features in the free and paid versions, they were suggested to upgrade to the pro version with the consequence of paying the subscription to get the full features.

After making sure that all participants had installed the application in the pro version, all the features in the application were explained covering how to use the application and the operational steps based on the criteria as in Table 3. After these stages, a survey was administered to explore the participants' perceptions towards the EHK91 application. The survey result is presented in Table 5.

Table 5. Participants' Perception towards EHK9I

\begin{tabular}{|c|c|c|c|c|c|c|}
\hline No. & Statement & SD & D & RD & $\mathbf{A}$ & SA \\
\hline 1 & $\begin{array}{l}\text { The EHK9I application grows my } \\
\text { motivation to learn more about hadith. }\end{array}$ & & & & 332 & 66 \\
\hline 2 & $\begin{array}{l}\text { The EHK9I application is very easy to } \\
\text { understand and practical to use. }\end{array}$ & & & & 380 & 18 \\
\hline 3 & $\begin{array}{l}\text { The EHK9I application is economical } \\
\text { compared to buying printed books }\end{array}$ & & & & 392 & 6 \\
\hline
\end{tabular}

Note: SD (Strongly Disagree), D(Disagree), RD (Rather Disagree), A (Agree), and SA (Strongly Agree)

Table 5 above showed that the participants stating that the EHK9I application fostered their motivation to explore the hadith. Moreover, EHK9I was very easy to understand and practical to use at an economic price compared to the price for having printed books so that it was affordable for all students.

\subsubsection{Step 5: Applying EHK9I in Takhrij Hadith Process}

The participants were guided to explore a hadith, in this case a hadith about reading al-Fatihah in shalat. There are several phases taken in this step.

\section{a. Exploring Hadith Text Using EHK9I}

The participants were instructed to open the EHK9I application. They were instructed to enter keywords. In entering keywords, they can search for them based on meaning, number, or hadith text. In terms of searching the hadith related to Surah Al-Fatihah, the keywords entered were "Al-Fatihah" or "Fatihatul Kitab". Using this search engine facility, the participants could also easily track the existence of the hadiths that are scattered online to find out the position of the hadith in the canonical books. The method used was by copying the hadith that was on the internet, then pasting it in the search bar, and it would appear whether or not the text of the hadith existed in the nine books book of hadith. 


\section{b. Identifying Sanad and Matan}

After entering the keywords, the display will appear as shown in Figure 2.

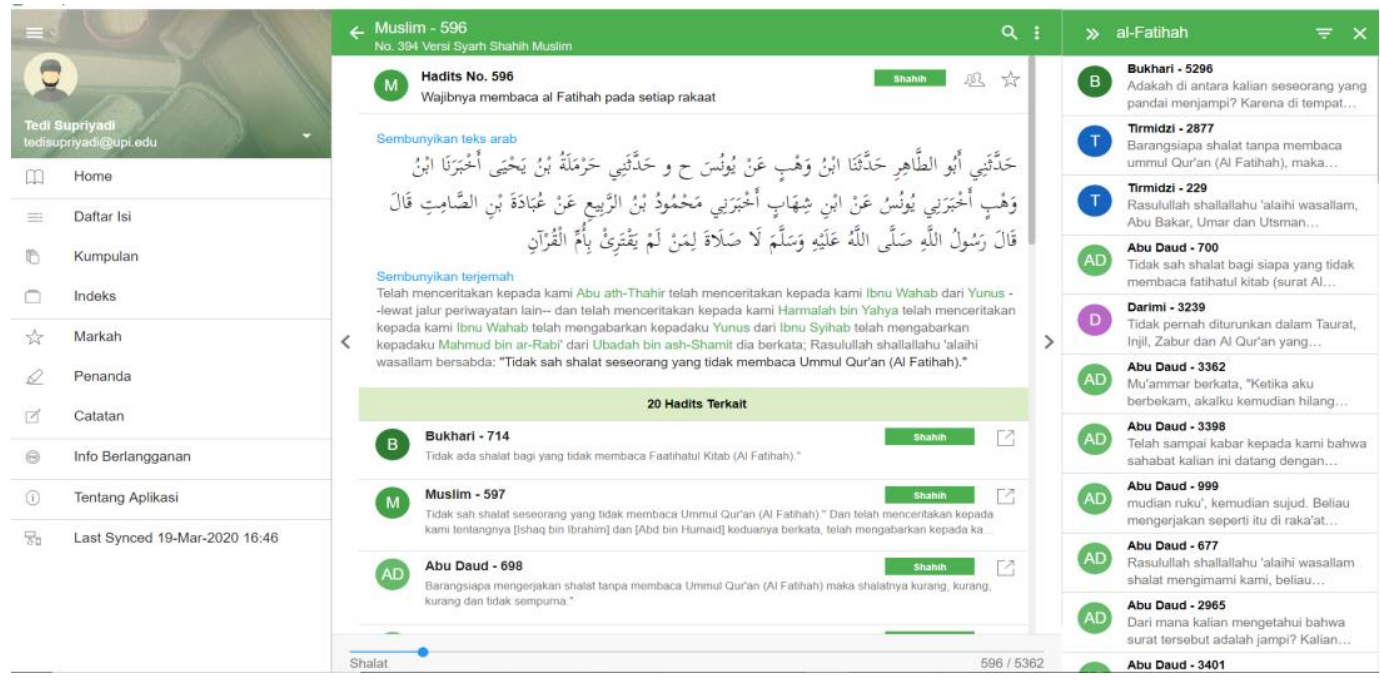

Figure 2. Display of Hadith related to Surah Al-Fatihah in the EHK9I Application

From the display, the participants were instructed to identify which ones were included as matan and sanad in the series of hadiths and to review hadith that were relevant to the ones displayed. After that, they were instructed to identify the similarities and differences between the matan and sanad, between the hadith being studied and the hadith that are considered relevant in the application.

\section{c. Analyzing and Assessing the Narrator in the Jarh Wa Ta'dil Framework}

After analyzing sanad and rawi, the participants were instructed to analyze the narrators of the hadith and explore information about the assessment of the narrators according to ulama jarh wa ta'dil. By clicking on number 3 as shown in the Figure 1, the biography of the narrator is presented, the number of hadith narrated and in any book, as well as the assessment of the ulama jarh wa ta'dil about the narrator. For example, in the hadith there was a narrator named Ahmad bin Amru bin Abdullah bin Amru as-Sarh. Then the information obtained from the narrator in the EHK9I application is shown in Figure 3.

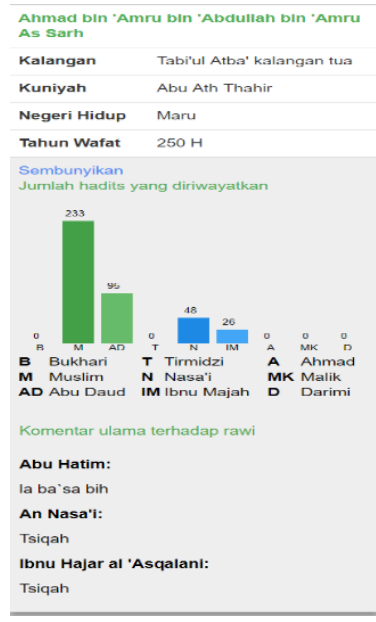

Figure 3. Display of the Narrator's Information 


\section{d. Determining the Authenticity of the Hadith Using the Application}

To determine the law or the quality of a hadith, the participants clicked no. 2 in Figure 1. Then the information related to the quality of the hadith was presented. By knowing the quality of the hadith, the participants could determine how reliable the hadith was in relation to its implementation as explained in the science of hadith.

\subsubsection{Step 6: Learning Evaluation}

After all of the steps and process conducted, this was the last step to portray the participants' hadith literacy skills related in the post-action. The participants were assigned to analyze the hadith around the topic of shalat. Then they were instructed to answer a number of questions related to the hadiths they were studying. The assessment was developed indicators presented in Table 1. By comparing the results of the pre-test as shown in Figure 1 and the results of the post-test, the evaluation of the practice of the takhrij hadith using EHK9I is described in Table 6.

Table 6. Hadiths Practice Evaluation Results Using EHK91

\begin{tabular}{|c|c|c|c|c|}
\hline No & $\begin{array}{c}\text { Literacy } \\
\text { Aspect }\end{array}$ & Description & Indicator & Percentage \\
\hline 1 & $\begin{array}{l}\text { Hadith Data } \\
\text { Literacy }\end{array}$ & $\begin{array}{l}\text { The ability to } \\
\text { read, analyze } \\
\text { and make } \\
\text { conclusions of } \\
\text { thinking based } \\
\text { on obtained } \\
\text { data and } \\
\text { information } \\
\text { (big data) }\end{array}$ & $\begin{array}{l}\text { a) Able to find and collect } \\
\text { thematic hadiths. } \\
\text { b) Able to distinguish elements } \\
\text { of the hadith (matan and } \\
\text { isnad). } \\
\text { c) Able to mention the } \\
\text { source/primary book related } \\
\text { to a hadith. } \\
\text { d) Able to express the content } \\
\text { of a hadith according to the } \\
\text { explanation of ulama. }\end{array}$ & $\begin{array}{l}96 \% \\
96 \%\end{array}$ \\
\hline 2 & $\begin{array}{l}\text { Hadith } \\
\text { Technology } \\
\text { Literacy }\end{array}$ & $\begin{array}{l}\text { Ability to } \\
\text { understand } \\
\text { machines and } \\
\text { technology } \\
\text { applications, } \\
\text { and do work } \\
\text { using } \\
\text { technology- } \\
\text { based products }\end{array}$ & $\begin{array}{l}\text { a) Able to utilize information } \\
\text { technology in studying } \\
\text { hadith. } \\
\text { b) Able to search for and } \\
\text { choose information } \\
\text { technology related to the } \\
\text { hadith appropriately } \\
\text { c) Able to understand the } \\
\text { features in the hadith } \\
\text { information technology } \\
\text { being used }\end{array}$ & $97 \%$ \\
\hline 3 & $\begin{array}{l}\text { Human } \\
\text { Literacy } \\
\text { related to } \\
\text { the } \\
\text { Narrator of } \\
\text { Hadith }\end{array}$ & $\begin{array}{l}\text { Communication } \\
\text { skills, } \\
\text { collaboration, } \\
\text { critical } \\
\text { thinking, } \\
\text { creativity and } \\
\text { innovation }\end{array}$ & $\begin{array}{l}\text { Able to express the quality } \\
\text { of a hadith accompanied by } \\
\text { the narrator's narration } \\
\text { analysis. } \\
\text { Able to respond to a hadith } \\
\text { that is used as a basis for } \\
\text { someone }\end{array}$ & $96.2 \%$ \\
\hline
\end{tabular}


Table 6 shows that by using the EHK9I resulted in an increase in the participants' ability to trace the authenticity of hadith in several indicators on each aspect used as the barometer of the hadith literacy skill.

\subsection{Post-Action Evaluation}

This stage is the implementation of the third R or Reflecting, which is evaluating the whole set of actions carried out in the research activities. This final stage was to gain an overview of the extent to which improvements had been achieved in solving the research problems. The learning results illustrated the fact that with the selection of appropriate learning media, the use of the Ulumul Hadith application and EHK9I was the appropriate solution to improve the participants' ability to trace the authenticity of a hadith (takhrij hadith). The increase occurred in line with the increasing literacy skills which included three aspects namely data literacy, technological literacy, and human literacy, which were assessed using indicators presented in Table 1. As an illustration of this improvement, a comparison between the hadith literacy in the pre-test and post-test stages is presented.

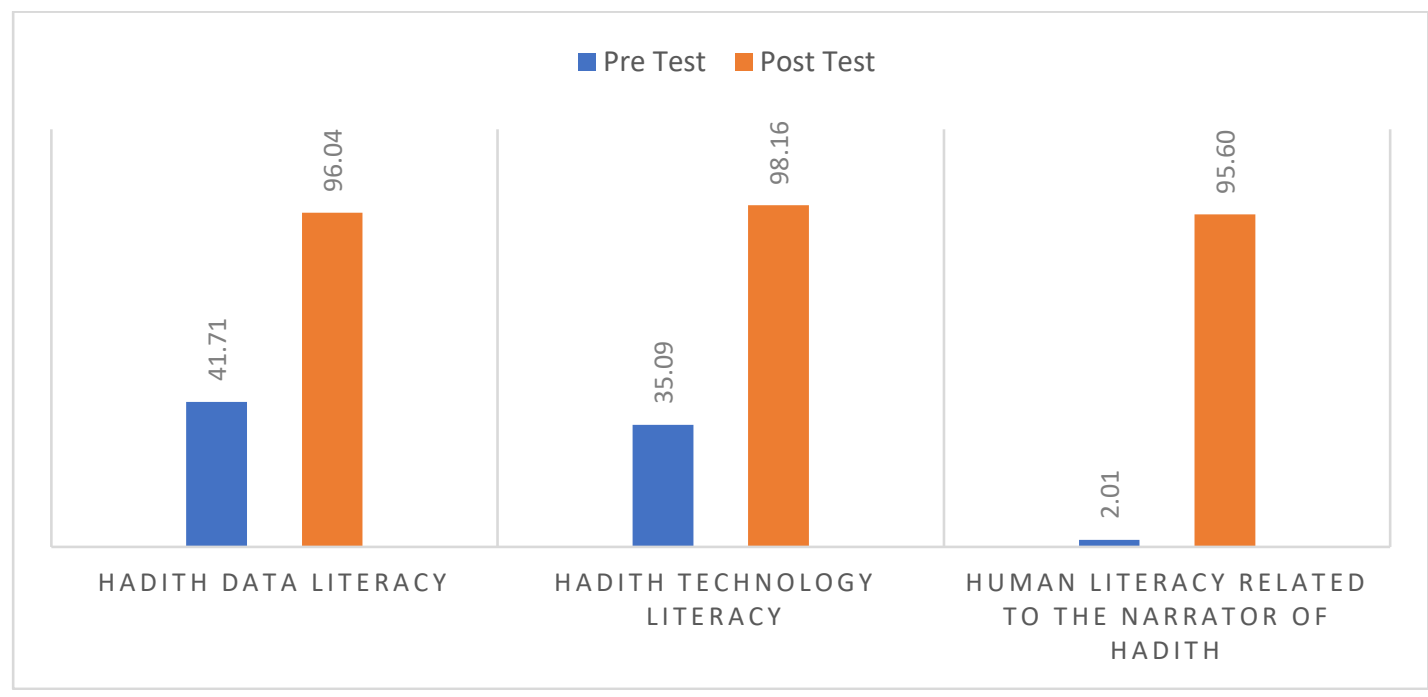

Figure 4. Comparison of Pre-Test and Post-Test Results of Hadith Literacy Skill

Figure 4 depicts that in the aspect of data literacy, the participants' ability was at $47.71 \%$ in the pre-test and then increased to $96.04 \%$ in the post-test. This means that in the aspect of data literacy, an increase of $54.33 \%$ were gained. In the aspect of technological literacy, the participants were at $35.09 \%$, and it increased to $98.16 \%$ in the post-test. this means that in the aspect of technological literacy an increase in capability is $63.07 \%$. In the human literacy aspect, the participants' ability increased to $95.6 \%$ from $2.01 \%$. This means that in the aspect of human literacy, an increase of $93.58 \%$ occurred. Thus, the use of Ulumul Hadith and EHK9I applications could improve the participants' hadith literacy.

\section{Discussion}

The ability to perform takhrij hadith is closely related to one's literacy skills in the field of hadith. Literacy is not limited to reading and writing but it is also related to the demand to understand information critically and analytically (UNESCO, 
2003). For the millennials who live in a digital era, special abilities are needed in using information in digital format, namely digital literacy (Miftah et al., 2016). Digital literacy is very important to have because someone's misunderstanding in the digital world opens up opportunities for various abuses of digital media that occur at the personal, social, and national levels (Pratiwi \& Pritanova, 2017). Therefore, literacy skills are must be possessed in the face of the $21^{\text {st }}$ century (Antoro, 2017, p. 5).

In facing the Industrial Revolution 4.0 or the era of disruption, "new literacy" is needed in addition to old literacy. Old literature includes the competence of read-write-count. Whereas, new literacy includes data literacy, technological literacy, and human literacy. Data literacy is related to the ability to read, analyze and make conclusions of thinking based on data and information (big data) obtained. Technology literacy is related to the ability to understand how machines work. Application of technology and technology-based work of products to get maximum results. Human literacy is related to communication skills, collaboration, critical thinking, creative and innovative (Furqon, 2018).

It can be understood that the literacy of the hadith in the 4.0 era is not only limited to the activities of reading and writing the hadith and analyzing the quality of the hadith. Rather, it includes data literacy, technology literacy, and human literacy. Data literacy is related to the ability to read, analyze, and make conclusions of thinking based on data and information (big data). Technology literacy is related to the ability to understand how machines work and technology applications, and to work using technology products to obtain maximum results. Human literacy is related to communication skills, collaboration, critical thinking, creativity, and innovation (Furqon, 2018).

The lack of hadith literacy skills in the information technology era affect vulnerable people in which they can be exposed to radical ideology. The internet or social media have become media for radicals and terrorists to propagate their radical narratives in the name of religion (Sulfikar, 2019). The internet makes it possible to spread information quickly, with little risk, and inexpensively to a variety of constituents, from potential recruits to potential partners in terrorist organizations (Seib \& Janbek, 2010). The results of Golose's research revealed that the efforts made by terrorist groups in the cyber world include 9P namely, Propaganda, Perekrutan (Recruitment), Pelatihan (Training), Penyediaan Logistik (Logistics Provision), Pembentukan paramiliter secara melawan hukum (Formation of unlawful paramilitaries), Perencanaan (Planning), Pelaksanaan serangan teroris (Conducting terrorist attacks), Persembunyian (Hiding), and Pendanaan (Funding) (Golose, 2015, p. 31).

That is why literacy skill is a social function of a person in using his literacy to contribute to the community (Keefe \& Copeland, 2011). The development of someone's literacy will be effective if done in a community context. This means that one's literacy ability is not only focused on improving cognitive abilities and processing information (Webber \& Johnston, 2000) but also utilizing it in the context of community development (Nuswantara \& Savitri, 2018). 


\section{Conclusion}

This research has shown the fact that the implementation of the Kern's (Kern, 2000) model of Responding, Revising and Reflecting in this research succeeded in showing an increase in the participants' literacy skills in the field of hadith. The increase could be seen in several aspects of literacy, namely in data literacy by $54.33 \%$, technological literacy by $63.07 \%$, and human literacy related to narration of the hadith by $93.59 \%$. These improvements indicated that the participants; literacy skills exceeded the target set by $75 \%$. In post-action, the data literacy was resented at $96.04 \%$, technology literacy at $98.16 \%$ and human literacy related to narration of hadith at $95.60 \%$. The increase is inseparable from the steps taken in the Revising phase, which produced six reflective action steps including the selection of Ulumul Hadith and EHK9I as the learning media. Using these applications in the learning process, the problems that occurred in the hadith learning process could be minimized. In addition, the application helped growing student's critical attitude in receiving hadith information in the cyberspace. They can validate the hadiths that are spread in cyberspace or in social media. The limitation of this study is that it only covers participants in the West Java region of Indonesia. The same problem in learning hadith can occur for academics outside the region and even in other countries. Therefore, it is recommended the application be translated into various languages and conducted in different regional-cultural areas.

\section{References}

Al-Fadli, A. al-H. (2011). Introduction to Hadith. ICAS Press.

Al-Rajan, A. R. A. (2018). The Science of Takhrij al-Hadith: a Comparison between Traditional and Electronic Modes. الدراسات الإسلامية Al-Dirasat Al-Islamiyyah, 53(1), 45-65. doi:10.12816/0048586

Al Asqalani, I. H. (2007). Fathul Baari: Penjelasan Kitab Shahih Al Bukhari (Vol. 4) [Fathul Baari: Explanation of Shahih Book of Al-Bukhari]. Jakarta: Pustaka Azzam.

Ali, M. M. (2013). Manual of hadith. Routledge.

Alkhatib, M., Monem, A. A., \& Shaalan, K. (2017). A Rich Arabic WordNet Resource for Al-Hadith Al-Shareef. Procedia Computer Science, 117, 101-110. doi:10.1016/j.procs.2017.10.098

Allen, I. E., \& Seaman, C. A. (2007). Likert scales and data analyses. Quality Progress, $40(7), 64-65$.

Antoro, B. (2017). Gerakan Literasi Sekolah dari Pucuk hingga Akar: Sebuah Refleksi [Literacy Movement from Buds to Roots: A Reflection]. Direktorat Jenderal Pendidikan Dasar dan Menengah.

Arifah, D. (2019). Hadis "Keutamaan Menyampaikan Sabda Nabi": Tinjauan Teori Common Link G.H.A. Juynboll. [Hadith stating "Preaching the Words of Prophet": Review of Gha Juynboll Common Link Theory]. Jurnal Living Hadis, 4(2), 181-207. doi:10.14421/livinghadis.2019.1928

Azmi, A., \& Bin Badia, N. (2010). iTree - Automating the construction of the narration tree of Hadiths (Prophetic Traditions). Proceedings of the 6th International Conference on Natural Language Processing and Knowledge Engineering(NLPKE-2010).(pp. 1-7). doi:10.1109/nlpke.2010.5587810

Azmi, A. M., \& Bin Badia, N. (2010). e-Narrator-An application for creating an ontology of Hadiths narration tree semantically and graphically. Arabian Journal for Science 
and Engineering, 35(2 C), 51-68.

Baraka, R. S., \& Dalloul, Y. (2014). Building Hadith ontology to support the authenticity of Isnad. International Journal on Islamic Applications in Computer Science and Technology, 2(1), 25-39.

Boutz, J., Benninger, H., \& Lancaster, A. (2019). Exploiting the Prophet's Authority: How Islamic State Propaganda Uses Hadith Quotation to Assert Legitimacy. Studies in Conflict \& Terrorism, 42(11), 972-996. doi:10.1080/1057610X.2018.1431363

Bozkuş, K. (2019). The Application of the Dynamic Teacher Professional Development Through Experimental Action Research. International Electronic Journal of Elementary Education, 11(4), 335-352. doi:10.26822/iejee.2019450792

Brigham, T. J. (2014). Taking advantage of Google's Web-based applications and services. Medical Reference Services Quarterly, 33(2), 202-210. doi: 10.1080/02763869.2014.897521

Brown, J. A. C. (2017). Hadith: Muhammad's legacy in the medieval and modern world. Oneworld Publications.

Bruce, C. D., Flynn, T., \& Stagg-Peterson, S. (2011). Examining what we mean bycollaborationin collaborative action research: a cross-case analysis. Educational Action Research, 19(4), 433-452. doi:10.1080/09650792.2011.625667

Chiu, C.-H., Cheng, H.-W., \& Wu, C.-Y. (2016). Applying questioning or reading strategy to review technology enhanced coedited notes of elementary school students. The Journal of Educational Research, 109(2), 111-121. doi:10.1080/00220671.2014.924471

Creswell, J. W. (2002). Educational research: Planning, conducting, and evaluating quantitative. Prentice Hall Upper Saddle River, NJ.

Darwis, R. S. (2017). Membangun Desain Dan Model Action Research Dalam Studi Dan Aksi Pemberdayaan Masyarakat. [Building Action Research Design and Model in the Study and Actions of Society Empowerment] Komunika: Jurnal Dakwah Dan Komunikasi, 10(1), 142-153. doi:10.24090/komunika.v10i1.869

Edwards-Groves, C., \& Kemmis, S. (2015). Pedagogy, Education and Praxis: understanding new forms of intersubjectivity through action research and practice theory. Educational Action Research, 24(1), 77-96. doi:10.1080/09650792.2015.1076730

Ferguson-Patrick, K. (2007). Writers develop skills through collaboration: an action research approach. Educational Action Research, 15(2), 159-180. doi:10.1080/09650790701314585

Furqon. (2018). Perlunya Literasi Baru Menghadapi Era Revolusi Industri 4.0 [The Significance of New Literact to Face the Era of Industrial Revolution 4.0]. Retrieved from https://www.uinjkt.ac.id/id/perlunya-literasi-baru-menghadapi-erarevolusi-industri-4-0/

Ghozali, A. M. (2017). Urgensi Digital Library Dalam Pemberdayaan Madrasah: Penggunaan Maktabah Syamilah versi 2.11 dalam Peningkatan Kualitas Pembelajaran Guru di MAN 1 Model Bandar Lampung [The Urgency of Digital LIbrary in Empowering Madrasah: Using Maktabah Syamilah Version 2.11 in Improving the Quality of Teachers' Learning at MAN 1 Model Bandar Lampung]. Cendekia: Journal of Education and Society, 15(2), 153. doi:10.21154/cendekia.v15i2.925

Gillen, J., Staarman, J. K., Littleton, K., Mercer, N., \& Twiner, A. (2007). A “learning revolution"? Investigating pedagogic practice around interactive whiteboards in British primary classrooms. Learning, Media and Technology, 32(3), 243-256. doi:10.1080/17439880701511099

Golose, P. R. (2015). Invasi terorisme ke cyberspace [The invasion of terorism to cyberspace]. Yayasan Pengembangan Kajian Ilmu Kepolisian.

Greenwood, D. J., \& Levin, M. (2006). Introduction to action research: Social research for social change. SAGE publications. 
Hidayat, A. (2018). Metode Takhrij Hadits Digital Dan Aplikasinya Pada Hadits Spionase [Takhrij Method of Digital Hadith and Its Applicatio on Spionage Hadith]. Al-Ahkam, 14(1), 39. doi:10.32678/ajh.v14i1.1481

Jaipal, K., \& Figg, C. (2011). Collaborative action research approaches promoting professional development for elementary school teachers. Educational Action Research, 19(1), 59-72. doi:10.1080/09650792.2011.547688.

Julia, J., \& Isrokatun, I. (2019). Technology Literacy and Student Practice: Lecturing Critical Evaluation Skills. International Journal of Learning, Teaching and Educational Research, 18(9), 114-130. doi:10.26803/ijlter.18.9.6.

Kamali, M. H. (2014). A textbook of Hadith studies: authenticity, compilation, classification and criticism of Hadith. Kube Publishing Ltd.

Karim, N. S. A., \& Hazmi, N. R. (2005). Assessing Islamic information quality on the Internet: A case of information about hadith. Malaysian Journal of Library $\mathcal{E}$ Information Science, 10(2), 51-66.

Keefe, E. B., \& Copeland, S. R. (2011). What is Literacy? The Power of a Definition. Research and Practice for Persons with Severe Disabilities, 36(3-4), 92-99. doi:10.2511/027494811800824507

Kemmis, S., \& McTaggart, R. (2005). Participatory action research: Communicative action and the public sphere. Sage Publications Ltd.

Kemmis, S., McTaggart, R., \& Nixon, R. (2013). The action research planner: Doing critical participatory action research. Springer Science \& Business Media.

Kern, R. (2000). Literacy and language teaching. Oxford University Press.

Leeman, Y., van Koeven, E., \& Schaafsma, F. (2017). Inter-professional collaboration in action research. Educational Action Research, 26(1), 9-24. doi:10.1080/09650792.2017.1301827

Lin, Y.-T., Chang, C.-H., Hou, H.-T., \& Wu, K.-C. (2015). Exploring the effects of employing Google Docs in collaborative concept mapping on achievement, concept representation, and attitudes. Interactive Learning Environments, 24(7), 1552-1573. doi:10.1080/10494820.2015.1041398

Luthfi, E. T., Suryana, N., \& Basari, A. H. (2018). Digital Hadith Authentication: A Literature Review and Analysis. Journal of Theoretical \& Applied Information Technology, 96(15).

Masrur, A. (2007). Teori common link GHA Juynboll [Theory of GHA Juynboll Common Link]. Lembaga Kajian Islam dan Sosial (LKIS).

McTaggart, R. (1994). Participatory Action Research: issues in theory and practice. Educational Action Research, 2(3), 313-337. doi:10.1080/0965079940020302

McTaggart, R. (1996). Issues for Participatory Action Researchers. New Directions In Action Research, 243-256. doi:10.4324/9780203392935_chapter_13

Messiou, K. (2019). Collaborative action research: facilitating inclusion in schools. Educational Action Research, 27(2), 1-13. doi: 10.1080/09650792.2018.1436081

Miftah, M. N., Rizal, E., \& Anwar, R. K. (2016). Pola Literasi Visual Infografer Dalam Pembuatan Informasi Grafis (Infografis) [Literacy Pattern of Infographer Visual in Making Infographic]. Jurnal Kajian Informasi Dan Perpustakaan, 4(1), 87. doi:10.24198/jkip.v4i1.11635

Mohamad, M. A., \& Mohamad, M. T. (2017). The Use of Khinzir Terms in Hadith Perspective: Conceptual Analysis in al-Kutub al-Sittah. Al-Bayān - Journal of Qur'ān and Hadith Studies, 15(1), 73-89. doi:10.1163/22321969-12340046

M. Najeeb, M. (2014). Towards Innovative System for Hadith Isnad Processing. International Journal of Computer Trends and Technology, 18(6), 257-259. doi:10.14445/22312803/ijctt-v18p154 
Najiyah, I., Susanti, S., Riana, D., \& Wahyudi, M. (2017). Hadith degree classification for Shahih Hadith identification web based. 2017 5th International Conference on Cyber and IT Service Management (CITSM). doi:10.1109/citsm.2017.8089304

Nasr, S. H. (2013). Islamic spirituality: foundations (Vol. 19). Routledge.

Niemi, R. (2018). Five approaches to pedagogical action research. Educational Action Research, n.v, 1-16. doi:10.1080/09650792.2018.1528876

Nirwana, D. (2012). Rekonsepsi Hadits dalam Wacana Studi Islam (Telaah Terminologis Hadits, Khabar dan Atsar [The Reconstruction of Hadith in the Discourse of Islamic Studies (Terminological Review of Hadith, Khabar and Atsar)]. Edu Islamika, 4(2), 289-313.

Nuswantara, K., \& Savitri, E. D. (2018). Mengembangkan Kampung Literasi sebagai Upaya Peningkatan Daya Berpikir Kreatif Imajinatif Anak-Anak Gang Dolly Melalui Penulisan Cerpen Layak Jual [Developing Literacy Village as an Effort to Enhance Imaginative Creative Thinking Power of Dolly Gang Children through Writing Worth-Selling Short Stories]. SEWAGATI , 2(1). doi:10.12962/j26139960.v2i1.3166

Parvez, Z. F. (2016). Prayer and pedagogy: Redefining education among Salafist Muslim women in France. Journal of Religious and Political Practice, 2(1), 23-39. doi:10.1080/20566093.2016.1085245

Peppler, K. A., \& Kafai, Y. B. (2007). From SuperGoo to Scratch: exploring creative digital media production in informal learning. Learning, Media and Technology, 32(2), 149166. doi:10.1080/17439880701343337

Pratiwi, N., \& Pritanova, N. (2017). Pengaruh Literasi Digital Terhadap Psikologis Anak Dan Remaja [Effects of Digital Literacy on Psychological Children and Adolescents]. Semantik, 6(1), 11. doi:10.22460/semantik.v6i1p11.250

Prensky. (2001). Digital natives, digital immigrant. Retrieved from http://www.marcprensky.com/writing/Prensky Digital Natives, Digital Immigrants - Part1.pdf

Qomarullah, M. (2016). Metode Takhrij Hadits dalam Menakar Hadits Nabi [Methods of Takhrij Hadith in Reciting Prophet's Hadith]. EL-Ghiroh, 11(2), 23-34. doi:10.37092/EL-GHIROH.V11I2.54

Rakhmah, S. N. (2016). Pembuatan Aplikasi E-Hadits Pada Smartphone Berbasis Java Eclipse [Making E-Hadith Java E-Clipse-based Applications on Smartphones]. Simnasiptek 2016, 1(1), 62-72.

Salomon, G., \& Clark, R. E. (1977). Reexamining the Methodology of Research on Media and Technology in Education. Review of Educational Research, 47(1), 99-120. doi:10.3102/00346543047001099

Seib, P., \& Janbek, D. M. (2010). Global terrorism and new media: The post-Al Qaeda generation. London: Routledge. doi:10.4324/9780203845370

Somekh, B. (2010). The Collaborative Action Research Network: 30 years of agency in developing educational action research. Educational Action Research, 18(1), 103-121. doi:10.1080/09650790903484566

Suherman, A., Supriyadi, T., \& Cukarso, S. H. I. (2019). Strengthening National Character Education through Physical Education: An Action Research in Indonesia. International Journal of Learning, Teaching and Educational Research, 18(11), 125-153. doi:10.26803/ijlter.18.11.8

Sulfikar, A. (2019). Swa-radikalisasi Melalui Media Sosial di Indonesia [Selfradicalization through Social Media in Indonesia]. Jurnal Jurnalisa, 4(1). doi:10.24252/jurnalisa.v4i1.5622

Suliaman, I., \& Yaakob, M. A. Z. (2019). Analysis on Textual Hadith of Waqf Infrastructure in al-Kutub al-Sittah and Its Applications from the Perspective of 
Maqasid al-Sunnah. Al-Bayān - Journal of Qur'ān and Ḥadīth Studies, 17(2), 221245. doi:10.1163/22321969-12340077

Suliaman, I., Zulkipli, S., Ramlan, A. M., Anas, N., Ahmat, A., Aziz, N., \& Yaakob, M. (2018). The convenience of takhrij al-hadith through ICT apps: An exploratory analysis on selected hadith website and mobile apps. International Journal of Civil Engineering and Technology (IJCIET), 9(11), 2649-2660.

Supriyadi, T., \& Julia, J. (2019). The Problem of Students in Reading the Quran: A Reflective-Critical Treatment through Action Research. International Journal of Instruction, 12(1), 311-326 doi: 10.29333/iji.2019.12121a.

Supriyadi, T., Julia, J., \& Iswara, P. D. (2019). Phonological Interference in Reciting AlQur'an: A Critical Reflection on the Learning of Al-Qur'an Phonology through Action Research. International Journal of Learning, Teaching and Educational Research, 18(9), 46-77. doi: 10.26803/ijlter.18.9.3.

Supriyadi, T., Julia, J., Iswara, P. D., \& Aeni, A. N. (2019). Eradicting Al-Qur'an Illiteracy of Prospective Primary School Teachers. Mimbar Sekolah Dasar, 6(2), 219-238. doi:10.17509/mimbar-sd.v6i2.16583

Suryadi, R. A. (2011). Hadits: Sumber Pemikiran Tujuan Pendidikan [Hadith: Thinking Source of Education Purpose]. Jurnal Pendidikan Agama Islam-Ta'lim Vol. 9 No. $2-$ 2011, 161-185.

Travis, L. (2010). One of Many Free Survey Tools: Google Docs. Journal of Electronic Resources in Medical Libraries, 7(2), 105-114. doi:10.1080/15424065.2010.482902

Tresnawati, D., Satria, E., \& Silviadi, D. (2016). Pengembangan Aplikasi Seratus Satu Hadis Tentang Budi Luhur Berbasis Multimedia [Development of A Hundred and One Hadiths on Nobility based on Multimedia]. Jurnal Algoritma, 13(1), 137-143. doi:10.33364/algoritma/v.13-1.137

UNESCO, Z. (2003). The Prague declaration: Towards an information literate society. United Nations Educational, Scientific and Cultural Organization.

Usman, A. H., \& Wazir, R. (2018). The Fabricated Hadith: Islamic Ethics And Guidelines Of Hadith Dispersion In Social Media. Turkish Online Journal Of Design Art And Communication, 8(SEPT), 804-808. doi:10.7456/1080sse/114

Wahyuningsih, S. (2019). The Hadith Digitization in Millennial Era: A Study At Center For Hadith Studies, Indonesia.

Webber, S., \& Johnston, B. (2000). Conceptions of information literacy: new perspectives and implications. Journal of Information Science, 26(6), 381-397. doi:10.1177/016555150002600602

Widhiarso, W. (2011). Skalo program analisis skala Guttman [Analysis of Scalo Program with Guttman Scale]. Yogyakarta, Indonesia: Universitas Gajah Mada.

Willett, R. (2007). Technology, pedagogy and digital production: a case study of children learning new media skills. Learning, Media and Technology, 32(2), 167-181. doi:10.1080/17439880701343352

Zech, L. K., Gause-Vega, C. L., Bray, M. H., Secules, T., \& Goldman, S. R. (2000). ContentBased Collaborative Inquiry: A Professional Development Model for Sustaining Educational Reform. Educational Psychologist, 35(3), 207-217. doi:10.1207/S15326985EP3503_6

Zulkipli, S. N., Yaacob, Z., Anas, N. B., Noor, M. S. B. M., Abidin, M. Z. H. B. Z., Jamil, W. K. N. B. W., \& Yakob, A. B. (2017). Takhrij al-Hadith Via Websites: A Study of al-Durar al-Saniyyah, Mawqi' al-Islam and Islamweb. PONTE International Scientific Researchs Journal, 73(4). doi:10.21506/j.ponte.2017.4.8 


\section{Appendix 1}

\section{RESEARCH INSTRUMENT 1}

Indicator Development of Literacy Aspect

\begin{tabular}{|c|c|c|c|}
\hline No & $\begin{array}{c}\text { Literacy } \\
\text { Aspect }\end{array}$ & Description & Indicator \\
\hline 1 & $\begin{array}{l}\text { Hadith Data } \\
\text { Literacy }\end{array}$ & $\begin{array}{l}\text { The ability to read, } \\
\text { analyze and make } \\
\text { conclusions of } \\
\text { thinking based on } \\
\text { obtained data and } \\
\text { information (big } \\
\text { data) }\end{array}$ & $\begin{array}{l}\text { 5. Able to find and collect thematic } \\
\text { hadiths. } \\
\text { 6. Able to distinguish elements of the } \\
\text { hadith (matan and isnad). } \\
\text { 7. Able to mention the } \\
\text { source/primary book related to a } \\
\text { hadith. } \\
\text { 8. Able to express the content of a } \\
\text { hadith according to the explanation } \\
\text { of ulama. }\end{array}$ \\
\hline 2 & $\begin{array}{l}\text { Hadith } \\
\text { Technology } \\
\text { Literacy }\end{array}$ & $\begin{array}{l}\text { Ability to } \\
\text { understand } \\
\text { machines and } \\
\text { technology } \\
\text { applications, and do } \\
\text { work using } \\
\text { technology-based } \\
\text { products }\end{array}$ & $\begin{array}{l}\text { 4. Able to utilize information } \\
\text { technology in studying hadith. } \\
\text { 5. Able to search for and choose } \\
\text { information technology related to } \\
\text { the hadith appropriately } \\
\text { 6. Able to understand the features in } \\
\text { the hadith information technology } \\
\text { being used }\end{array}$ \\
\hline 3 & $\begin{array}{l}\text { Human } \\
\text { Literacy related } \\
\text { to the Narrator } \\
\text { of Hadith }\end{array}$ & $\begin{array}{l}\text { Communication } \\
\text { skills, collaboration, } \\
\text { critical thinking, } \\
\text { creativity and } \\
\text { innovation related to } \\
\text { the hadith narrators }\end{array}$ & $\begin{array}{l}\text { 3. Able to express the quality of a } \\
\text { hadith accompanied by the } \\
\text { narrator's narration analysis. } \\
\text { 4. Able to respond to a hadith that is } \\
\text { used as a basis for someone }\end{array}$ \\
\hline
\end{tabular}

\section{RESEARCH INSTRUMENT 2}

Questions Items on a Test

\begin{tabular}{|c|l|}
\hline No & \multicolumn{1}{|c|}{ Questions } \\
\hline 1 & Find one hadith related to shalat. \\
\hline 2 & From the answer of question no 1, mark which one is rawi and sanad. \\
\hline 3 & From the answer of question no 1, what is the source of that hadith? \\
\hline 4 & Explain the content of that hadith according to one ulama. \\
\hline 5 & $\begin{array}{l}\text { Do you use information and technology or application in finding the hadith? If } \\
\text { so, what is the application you use? }\end{array}$ \\
\hline 6 & If you're using IT or software application, do you know how to operate it? \\
\hline 7 & Does the use of IT help you to learn hadith? \\
\hline 8 & From the answer of question no 1, how is the quality of that hadith? \\
\hline 9 & Comment on your friend's cited by a peer, seen from the quality and content. \\
\hline
\end{tabular}




\section{RESEARCH INSTRUMENT 3}

\section{Survey}

\begin{tabular}{|c|l|}
\hline No & \multicolumn{1}{|c|}{ Questions on Literacy Aspect } \\
\hline 1 & Have you ever studied the science of hadith? \\
\hline 2 & Have you ever received lessons about hadith in school? \\
\hline 3 & Have you ever received lessons about hadith outside of school? \\
\hline 4 & Have you sufficiently understood the terminilogy of hadith and kinds of hadith? \\
\hline 5 & Have you sufficiently understood the elements that a hadith must have? \\
\hline 6 & $\begin{array}{l}\text { Have you sufficiently understood the division of hadiths by their quality and } \\
\text { requirements? }\end{array}$ \\
\hline
\end{tabular}

\section{RESEARCH INSTRUMENT 4}

\section{Hadith Insight Test}

\begin{tabular}{|c|l|}
\hline No & \multicolumn{1}{|c|}{ Questions on Literacy Aspect } \\
\hline 1 & Mention aspects related to hadith. \\
\hline 2 & From the hadith you cited, which one is sanad and matan? \\
\hline 3 & How about its hadith classification seen from the quality and the characteristics? \\
\hline
\end{tabular}

\section{RESEARCH INSTRUMENT 5}

Survey on the EHK9I

\begin{tabular}{|c|c|c|c|c|c|c|}
\hline No. & Statement & SD & D & RD & A & SA \\
\hline 1 & $\begin{array}{l}\text { The EHK9I application grows my } \\
\text { motivation to learn more about hadith. }\end{array}$ & & & & & \\
\hline 2 & $\begin{array}{l}\text { The EHK9I application is very easy to } \\
\text { understand and practical to use. }\end{array}$ & & & & & \\
\hline 3 & $\begin{array}{l}\text { The EHK9I application is economical } \\
\text { compared to buying printed books }\end{array}$ & & & & & \\
\hline
\end{tabular}

Note:

$\mathrm{SD}=$ Strongly Disagree

$\mathrm{D}=$ Disagree

$\mathrm{RD}=$ Rather Disagree

$\mathrm{A}=$ Agree

$\mathrm{SA}=$ Strongly Agree 